II.-On some new Genera and Species of Araneidea. By the Rev. O. P. Cambridge, M.A., C.M.Z.S., \&c.

[Plates VI. \& VII.]

Six out of the eleven spiders here described are from Australia, two from South America, two from Madagascar, and one from Ceylon. 'Those from Madagascar are of very great interest; one (Phoroncidia aurata) is a peculiarly brilliant species of Prof. Westwood's curious genus; the other (Augusta papilionacea) is the type of a new genus, forming a link between the Gasteracanthides and the remarkable spiders of the genus Arcys (Arkys, Walck.). The general appearance of this spider is very striking, and reminds one of a small butterfly.

My thanks are due to the authorities at the British Museum for kindly permitting me to describe and figure those of the above spiders belonging to the family Theraphosides, the types of which are in the national collection. The remainder are described and figured from examples in my own possession.

\title{
Order ARANEIDEA.
}

\section{Fam. Theraphosides.}

\section{Gen. nov. Atrax.}

\section{Generic characters.}

Cephalothorax much longer than broad, lateral constriction at caput slight; fore part truncate, and rather narrower than the hinder part; caput not much elevated above the thorax, though rather roundly convex.

Falces large, massive, and very prominent, but with no teeth at the fore extremity of the upperside.

Eyes small and not greatly unequal in size; their position is very nearly that of Nemesia, the four exterior ones (being the laterals of each row) forming a transverse oblong figure whose fore side is rather shorter than the hinder one; and within this oblong is another shorter one, formed by the fore and hind central pairs of eyes, and whose fore side is considerably shorter than the hinder one.

Legs moderately long, strong; terminal claws three; no scopula at the extremities. Relative length 4, 1, 2, 3 .

Maxilla long, cylindrical, but prominent in an obtusely pointed form at the inner side of the fore extremity.

Labium short, of a round-oval form, rather truncated at the apex. 


\section{Atrax robustus, sp. n. (Pl. VI. fig. 1.)}

Adult female, length 13 lines, to end of falces 16 lines.

The whole of the fore part of this spider is of a deep rich red-brown colour; the cephalothorax smooth, shining, and destitute of hairs; the colour, however, of the falces is rather darker, and the fang is long and strong.

The legs do not differ greatly in length; and their armature consists of hairs, slender bristles, and a few spines.

The labium, which is convex in front, is studded with small tooth-like spines, a large portion at the base of the maxillæe being also similarly furnished.

The abdomen (in the only specimen examined, a dried one) was much shrunken; it is hairy, and its colour is a dark reddish brown. The spinners, four in number (?), were broken off.

A single example of this spider, from New Holland, is in the British-Museum collection.

\section{Gen. nov. IdiophthaLma.}

\section{Generic characters.}

Cephalothorax oblong-oval; fore part and hinder part about equal in width; rather flattened, but the occipital portion somewhat roundly convex.

Eyes in three transverse rows, very similar to Idiops \&c., but differing in the greater length of the front row and the contiguity of the outer eye, at each end of the hinder row, to the one next to it, forming two pairs considerably removed from each other. The hinder row is the longest, consisting thus of four eyes, and the middle row the shortest.

Falces strong and bristly, furnished with a group of strong spines on the upperside of their fore extremity.

Legs moderate in length, strong, furnished with hairs and bristles only, the metatarsi and tarsi with a compact scopula. The legs of the fourth pair were wanting; the relative length of the rest is $1,2,3$.

Maxillae long, cylindrical, and slightly curved.

Labium oblong, slightly broader at the apex (which is truncated) than at the base.

\section{Idiophthalma suspecta, sp. n. (Pl. VI. fig. 2.)}

Adult female, length $6 \frac{1}{2}$ lines, including falces $8 \frac{1}{4}$.

The colour of the cephalothorax, legs, and palpi is dark reddish brown, the falces being of a deeper brown than the cephalothorax; abdomen brown. 
A single example of this spider, from Granada, South America, is in the British-Museum collection. Although allied to Idiops, Perty, it appears to me to be generically distinct from that as well as from other allied genera, Idiosoma, Auss., Idioctis, L. Koch, and Idiommata, Auss.

\section{Gen. nov. Aganippe.}

\section{Generic characters.}

Cephalothorax longer than broad, and its fore extremity rather narrower than the hinder part; caput tolerably and roundly elevated.

Falces massive, furnished with a group of strong tooth-like spines at the fore extremity.

Legs short and strong, relatively 4, 3, 2, 1 (?) ; terminal claws three, with scopula beneath the tarsi and metatarsi of the first and second pairs, as well as under the digital joints of the palpi.

Eyes minute, but occupying a large area, and disposed in three transverse rows, $2,2,4$, and somewhat like those of Idiops, but more widely separated, and the front row very much longer in comparison to the rest.

Maxilla moderately long, cylindrical, and slightly curved.

Labium oblong, its sides nearly parallel, and its apex truncate.

This genus appears to be intermediate between Idiops and others of that group and Eriodon.

\section{Aganippe subtristis, sp. n. (Pl. VI. fig. 3.)}

Adult female, length $10 \frac{3}{4}$ lines, including falces rather over $12 \frac{1}{2}$.

The colour of the cephalothorax, falces, legs, and palpi is yellow-brown; the eyes form a broad transverse oblong figure, whose fore side is shorter, but not very greatly so, than the hinder one; the middle row is much the shortest; and the hinder row (consisting of four eyes) is slightly curved, the convexity of the curve directed forwards; the two central eyes of this row are more than double the distance from each other that each is from the lateral eye on its side of the same row.

The legs (of which the third and fourth pairs are the strongest) are furnished with hairs and bristles, the genual, tibial, and metatarsal joints of those of the third pair being armed with numerous short and strong spines on their outer sides.

The abdomen (much shrunken, but probably of the form given in the figure) is brown and hairy. 
A single example of this species is in the British-Museum collection. Hab. Adelaide.

\section{Aganippe latior, sp. n. (Pl. VI fig. 4.)}

Adult female, length nearly 11 lines.

This spider is evidently of the same genus as the last, though readily distinguishable by some strong differential characters. It is smaller, the cephalothorax is shorter and proportionally broader, and the falces are more powerful; the eyes also are smaller, and the figure formed by them has its fore side shorter and its longitudinal less in proportion to its transverse diameter.

The whole of the fore part of this spider is of a dark, shining, reddish yellow-brown colour. The cephalothorax is short, broad, and massive, the caput well and roundly elevated.

The falces are very strong, furnished in front with hairs and bristles disposed in longitudinal stripes, and armed with a group of strong spines on the upperside of their fore extremity.

The eyes are very minute but not very different in size; they form an area whose transverse diameter (at the hinder side) exceeds its longitudinal diameter taken in the middle, disposed in three transverse lines, 2, 2, 4, the foremost line being equal in length to that formed by the two middle eyes of the third (or hinder) row; while in A. subtristis the foremost line exceeds in length that formed by the two hind central eyes.

The legs are short and strong, those of the third and fourth pairs being the strongest; their relative length is $1,2,3,4$, though the difference between those of the first and second pairs is very slight; and in their armature, as well as in that of the palpi, they are similar to A. subtristis, though the spines on the third pair are perhaps not quite so numerous.

The abdomen is hairy and of a warm reddish brown colour; but it was too shrunken to give any exact idea of its form.

A single example is contained in the British-Museum collection. Hab. West Australia.

\section{Genus Eriodon, Latr.}

\section{Eriodon insignis, sp. n. (Pl. VI. fig. 5.)}

Adult male, length 5 lines, to extremity of falces $6 \frac{1}{2}$ lines. The cephalothorax of this spider is almost circular, the fore part being slightly truncated; the curve of that part is flattened. The colour of the caput and falces is a bright but rather 
brickish orange-red, that of the thorax being brownish black and covered with slightly tuberculous granulosities.

The legs and palpi are of a dark shining brown colour, tinged very slightly with metallic purplish; the former are short and strong, but not very different in length, those of the third pair being rather the shortest; they are furnished with hairs, bristles, and some short spines on the inner side of the genua of the first pair, and on the outer side of those of the third pair, with some longer and stronger ones beneath the tibiæ and metatarsi of the first pair; the tarsi terminate with three toothed claws.

The palpi are long, the radial joint about double the length of the cubital, and considerably tumid beneath the hinder half; the digital joint is small; and the palpal organs consist of a roundish basal bulb prolonged into a long, curved, tapering but not very sharp-pointed corneous process.

The falces are of great size and very prominent; their surface is granulose; and they have a cluster of tooth-like spines on the inner side of the fore extremity.

The abdomen, which was very much shrunken, projects well over the base of the cephalothorax; it is hairy and of a sooty black colour.

A single example of this very striking species is in the British-Museum collection. Hab. Swan River, Australia *.

\section{Eriodon incertus, sp. n.}

Adult male, length (without the falces) $6 \frac{1}{2}$ lines.

This spider is very closely allied to the preceding (Eriodon insignis); after close examination, however, I am inclined to think it is of a distinct species, differing not only in its larger size (which is, perhaps, inconstant), but in its longer palpi, in the more strongly constricted bulb of the palpal organs, in the outer eyes of the front row, which are larger, and in some other respects.

The colour of the cephalothorax is pitchy black with a slight bottle-greenish hue, and is more roughly granulose than that of Eriodon insignis; the falces also are more granulose, and their colour is black on the basal half, the fore half being of a pinkish orange-red.

* Since the above was in press Prof. Ausserer's “Zweiter Beitrag zur Kenntniss der Territelaria," Verh.z.-b.Ges. Wien, 1875, vol. xxv., has come to hand; in this work an Eriodon (E. rubrocapitatus), very nearly allied to, if not the same species as, $E$. insignis, is described and figured (p. 140, pl. v. figs. 1, 3, 4). As, however, the identity of the two does not at present appear to me quite certain, I have not recorded the BritishMuseum example as synonymous with Prof. Ausserer's spider. 
The legs and palpi are of a bright shining metallic purplebrown colour; the inner sides of the genua of the first and second pairs (chiefly of the first pair) are thickly furnished with spines, as also are the outer sides of the same joints of the third and fourth pairs.

The abdomen is small, hairy, and of a sooty brown colour, projecting strongly over the base of the cephalothorax.

This example is also from the Swan River, and in the British-Museum collection, where there is likewise a third specimen from the same locality; this last is (an adult $0^{*}$ ) of the same species as that now described, but differs from it in the entire falces being of a pinkish orange-red colour and the caput slightly tinged with the same hue; its size is also smaller, being the same as that of E. insignis.

\section{Fam. Phoroncidides.}

\section{Genus Phoroncidia, Westw.}

Phoroncidia aurata, sp. n. (Pl. VII. fig. 9).

Adult female, length $2 \frac{1}{3}$ lines, breadth of abdomen nearly 2 lines.

The cephalothorax is round-oval and tolerably convex above, the caput elevated and produced in a somewhat bent form, the occipital portion being rather gibbous; consequently the clypeus is high, deeply impressed in the middle, and prominent at its lower margin. The colour of the cephalothorax, as well as of the rest of the fore part, is a bright orange-redbrown; the greater part, however, of the legs of the fourth pair is strongly suffused with black.

The eyes are placed in a tolerably compact group of four pairs at the extremity of the caput; the fore and hind central pairs form nearly a square, whose longitudinal is rather greater than its transverse diameter; those of each lateral pair are placed in almost a straight liue with the fore central eye on its side; the laterals and fore centrals thus form a semicircular line; the latter are the largest of the eight, and the laterals the smallest.

The legs are short but rather strong, their relative length being $1,4,2,3$; and the genual joints are rather abruptly bent downwards near their hinder extremity; their armature consists of a few hairs only; and the tarsi terminate with three claws.

The palpi are short and slender, furnished with hairs only, and destitute of a terminal claw. 
The falces are short and not particularly powerful; they are armed with two small blackish teeth close together, at the fore extremity on the inner side.

The maxilla, labium, and sternum are normal in their form, the maxillæ being also furnished with a strong tuft of long: black bristles on their inner surface.

The abdomen is large, nearly round when looked at from above, and of a short pear-shape when seen laterally, the spinners forming the stem, these organs being placed at the extremity of a truncated cone of a coriaceous nature. The whole of the abdomen is of a corneous nature; the upper part and sides are of a bright golden hue and metallic lustre; four tolerably long, strong, divergent, and sharp-pointed, tapering, black spines occupy the upper corners, and form very nearly a square; between the two hinder ones, but a little way within their straight line, is a fifth spine of the same character though not quite so long nor so strong as the rest. Each of these spines consists of a truncated conical basal portion, prolonged by a sharp terminal spine; and their surface is furnished with a few minute tubercles or granulosities, which may originally have had hairs springing from them; but if so, these had been accidentally rubbed off. The whole of the abdomen is more or less covered with reddish and dark red-brown spots of various sizes, some of these being ocellated and the larger ones forming the pattern shown in the figures (Pl. VII.). The surface around the bases of the spines, as well as the whole of the underside and a large patch on the hinder part of the abdomen, are strongly suffused with orange-red.

Two examples of this beautiful and brilliant species were received from Madagascar in 1875, through the kindness of Mr. R. H. Meade, of Bradford, Yorkshire. It is a very distinct species from any yet described, and the most striking, perhaps, among the few known spiders of this remarkable genus.

\section{Fam. Gasteracanthides.}

Gen. Paraplectana, Capello (1866).

Eurysoma, Koch \& Blackw, ad part.

Peniza, Thorell (1868).

Paraplectana maritata, sp. n. (Pl. VII. fig. 7.)

Adult female, length 2 lines, breadth of abdomen nearly 2 lines.

This very pretty and distinct spider has the broad, massive cephalothorax of a uniform pale luteous yellow colour, shining, 
and furnished with a few fine hairs; the caput is large, much elevated above the height of the thorax, and rather roundly sloping from the occiput to the eyes; the occipital slope is abrupt and rather hollow.

The eyes are in three widely separated groups, close to the fore margin of the caput, leaving a clypeus of very small height; the central group of four eyes, seated on a black patch, forms very nearly a square, whose hinder side is the longest, the two eyes forming this side being the largest of the eight; the eyes of the lateral pairs are the smallest, and those of each pair are seated contiguously on a small tubercle quite at the fore corner of the caput.

The legs are short, tolerably strong, and not very greatly different in length; they are of a dark blackish brown hue, the basal joints, as well as a portion of the tibiæ and metatarsi of the third and fourth pairs, being brownish yellow; they are furnished with hairs, bristles, and a few spines, the latter chiefly on those of the first and second pairs.

The palp $i$ are moderately long and slender, similar in colour to the legs, and furnished with hairs and strongish bristles.

The falces are long and powerful, their direction being nearly vertical. At their base their colour is like that of the eephalothorax, deepening, however, to a dark brown at the extremity.

The maxilla, labium, and sternum are of normal character, and their colour is deep brown-black.

The abdomen is large, as nearly as possible round, moderately convex above, and projects over the cephalothorax to the highest part of the caput; the upper surface is of a corneous nature, though the usual boss-like markings are some of them obsolete and the rest very indistinct; its colour is a cream-white, marked with some large and generally welldefined black patches and spots; the nature of these will be best understood by reference to the figure (Pl. VII.): there is some little variation in the extent of these black markings; but they are always easily traced, and generally very conspicuous on the clear white ground-colour. The underside is black-brown; and the sides are longitudinally wrinkled. The spinners are short, compactly grouped, and of a dark brown colour.

The male is smaller than the female, being $1 \frac{1}{2}$ line in length; the legs of the first and second pairs are longer; and all the legs are of a brownish yellow colour, the femoral and genual joints more or less suffused with dark brown.

The palpi are short, the digital joints large, and, together with the palpal organs, form a mass of, comparatively, an enorAnn. \& Mag. N. Hist. Ser. 4. Vol. xix. 
mous size. These organs consist of a congeries of bold corneous spines and processes; the radial joint is short but wide, and is divided into several prominent apophyses.

The abdomen is more of an oval form than that of the female, its length being a little greater than its breadth; the upper surface is thickly covered with somewhat shining and apparently slightly depressed pale amber-coloured spots; the black pattern so conspicuous in the female is but just traceable in the male, being ill-defined and mostly of a dull yellowish brown colour on a cream-yellow ground, the ground-colour in this sex, however, being of small extent, and assuming the nature of large ill-defined spots. In all the males examined the dark patch at the hinder extremity of the upperside of the abdomen is of a deep blackish brown.

Adults of both sexes of this very striking little spider were received from Mr.J.H. K. Thwaites, by whom they were found in the Royal Botanic Gardens in Ceylon.

\section{Paraplectana decora, sp. n. (Pl. VII. fig. 8.)}

Adult female, length $2 \frac{1}{2}$ lines (nearly); length of abdomen nearly 2 lines.

The cephalothorax and falces are of a rich dark red-brown colour; the caput is broad, massive, well rounded above; and the height of the clypeus exceeds the length of the figure formed by the four central eyes.

The eyes are small, disposed in three widely separated groups; those of the central group form a small square, whose longitudinal is rather greater than its transverse diameter, and its fore side rather shorter than its hinder one; those of each lateral pair are seated contiguously on a small tubercle, very near the margin, at one of the fore corners of the caput, and are the smallest of the eight, the hinder ones of the central group being the largest.

The legs are short, moderately strong, of a yellow-brownish colour, and furnished with hairs and bristles; they differ but little in length, those of the third pair being the shortest.

The palpi are moderate in length, slender, of a pale dull yellowish colour, and clothed with hairs and bristles, a few of the latter having a spine-like character.

The falces are tolerably long, powerful, and nearly vertical in their direction.

The maxillae, labium, and sternum are of the normal type; and their colour is a dark reddish brown, the sternum being nearly black.

The abdomen is nearly round, being very slightly less 
rounded behind than at its fore extremity. Its upper surface is moderately convex and of a corneous nature, the usual ocellated marks or bosses being faintly marked, and this principally round the margins of the hinder half; its colour is a dark rich brownish black tinged with maroon, and marked with twelve distinctly defined yellow spots of different sizes and shapes, three forming a triangle near the centre, and the rest equally disposed round the outer margins, the one on each side of the middle of the fore extremity being the largest. The sides and underside are wrinkled and of a deep blackish brown colour.

A single example of this very pretty spider was contained in a collection made for me on the Rio Grande (South America) by Mr. Henry Rogers, of Freshwater, in the Isle of Wight.

\section{Paraplectana Kochii, sp. n. (Pl. VII. fig. 10.)}

Adult female, length $3 \frac{1}{4}$ lines (nearly); longitudinal diameter of the abdomen $2 \frac{3}{4}$ lines, transverse diameter $3 \frac{2}{3}$.

The whole of the fore part of this spider is of a deep redbrown colour, the tarsi (and metatarsi of the first three pairs) of the legs annulated with yellow.

The cephalothorax is of the ordinary massive form, the caput elevated into a high, transverse, rounded ridge, and constricted laterally near its fore margin; its surface is roughened and clothed with fine grey hairs.

The eyes are in three widely separated groups, near the fore margin of the caput; they are small, and do not differ much in size; the central group of four forms a square whose hinder side is longer than the rest; the posterior pair of these eyes are the largest of the eight; those of each lateral pair are seated very near together (but not contiguously) close to the lower fore corner of the caput; the height of the clypeus (in the middle) is rather less than half that of the facial space.

The legs are short and strong, furnished with hairs only, of which some are greyish white.

The palpi are short and rather slender; their colour is deep red-brown; and they are furnished with hairs, like the legs.

The falces are moderate in length but very powerful; their form is conical, their direction vertical, and the basal half in front is rugulose.

The maxille and labium are of normal form, red-brown with pale extremities, and the sternum rugulose, like the base of the falces.

The abdomen is large and oval, its transverse diameter considerably exceeding its longitudinal; its upperside is pretty 
convex, its surface corneous, minutely punctured, and marked with a marginal row of large round and oval boss-like spots of different sizes, and impressed in the usual way in their centres; four other similar markings describe nearly a square in the middle, with a much smaller one on each side of its fore part. The six middle anterior marginal markings, as well as the fore halves of the two anterior central ones, are of a bright orange colour on a paler ground; the rest of the upper surface of the abdomen is of a dull sooty hue, the bosslike markings being of a deep blackish red-brown colour. The underside of the abdomen is of a dull yellowish brown hue, wrinkled and covered thickly with minute dark redbrown tubercles, each of which is surmounted by a short bristle.

A single example of this spider was received from Cape York, and is (so far as I know) the first recorded species of the genus yet known on the Australian continent. It is with great pleasure that I connect with it the name of Dr. Ludwig Koch, the able author of 'Die Arachniden Australiens.'

\section{Fam. Arcydes.}

\section{Gen. nov. Augusta.}

\section{Generic characters.}

Cephalothorax broad and rather flattened, truncated before, and rounded behind; caput very distinctly divided from the thorax, which it also exceeds in breadth; it has a deep notch or incision on each side near the fore extremity ; and its lateral upper margins are sharp-edged.

Eyes eight, in three widely separated groups; a central one of four, forming nearly a square in the centre, is situated close to the fore margin of the clypeus, and two others on each fore corner, seated on the portion divided from the rest of the caput by the incision before noticed.

Legs short and tolerably strong; relative length 4, 1, 2, 3 .

Maxilla short, broad at their extremity, and bent strongly downwards towards the sternum.

Labium broad and short, of a somewhat semicircular form, pointed at the apex.

Abdomen covered with a large and nearly flat scutum, of a subtriangular form, the base of the triangle being in front; its upper and under sides are completely occupied with shining patches, varying in size, but nearly all of a pentagonal form, the dividing portions or ribs being almost all of a uniform width, and furnished with very minute, corneous, shining and 
bristle-bearing tubercles, the longitudinal central rib also marked with a few impressed spots or pock-like punctures; the entire margin is studded thickly with small shining tubercles of a similar kind, each furnished with a short bristle; and the two fore corners are armed with a strong but not very sharp-pointed spine.

\section{Augusta papilionacea, sp. n. (Pl. VII. fig. 6.)}

Adult female, length 4 lines; breadth of the widest part of the abdomen 6 lines.

The whole of this very interesting and curious-looking spider is of a yellow-brown colour, the abdomen being of a paler and duller hue than the cephalothorax-the tarsi, metatarsi, tibiæ, and genua of the legs being strongly suffused with red-brown. The caput is large, of a somewhat quadrate form, very slightly convex above; the lateral edges of the upperside behind the lateral eyes, as well as the fore margin, are rather sharp and studded with small tubercles, each of which is furnished with a short bristly hair; the upper surface of the caput is marked with small yellow-brown spots, of a deeper hue than the rest of the surface, mixed with a few very minute redbrown tubercles; and there is a large shallow roundish depression on either side towards the occiput, and a well-marked longitudinal groove from between the hind central eyes to the thorax.

The eyes are of a pale amber-colour, and not very greatly different in size; the four central ones form a square whose hinder side is rather the longest; this group is placed close to the fore margin of the caput, so that the clypeus is almost obsolete; each of the lateral pairs of eyes is seated close below the outer edge of the fore corner of the caput, on a quasitubercular area formed by a deep notch or indentation in its lateral margin; the eyes of these lateral pairs respectively are not contiguous to each other, being separated by at least, if not more than, the diameter of one of them.

The legs are short and tapering in form, and do not differ greatly in length; those of the first and second pairs are much stronger than the rest, and though there seems to be a little difference between them in the actual lengths of some of the joints, the total length appears to be as nearly as possible equal; those of the fourth pair are the longest, and the third pair are the shortest; all are furnished with hairs and bristles (of which latter a few have a spine-like character) and terminate with three claws, the two superior ones curved and pectinated, and the inferior one, after its sharp bend at the base, almost straight. 
The palpi are short and tolerably strong; their colour is similar to that of the legs, and they are also furnished with hairs and numerous spine-like bristles, the terminal claw being slightly curved and finely pectinated.

The falces are strong, rather prominent near their base in front, where they are also thickly marked with somewhat quadrate dull yellow-brown blotches; and thence to their extremities on the inner surface there are numerous strong bristles, some of which are of a spinous character.

The sternum is of a short oval form, truncate before and produced into a point behind, at the extremity of which as well as opposite the insertion of each of the first three pairs of legs is a small tubercle.

The abdomen is quite flat and of a subtriangular form, the apex forming the hinder extremity, which is bifid or broadly notched. Each of the numerous pentagonal shining compartments into which its surface (both above and below) is mapped out has a large central oval depression, made more conspicuous by a brown spot; the fore margin is slightly scalloped, hollow in the middle, enlarging and rounding on either side to the fore corner, which is armed with a strong, deep, blackish red-brown, slightly curved, but not very sharppointed spine; between this spine and the central hollow part of the fore margin there are, on each side, at the salient points of the scalloped border, four small, brown, blunt-pointed tuberculiform spines; the whole of the margins of the abdomen, both above and below, are thickly studded with minute round, brown and shining tubercles, each of which bears a small bristle; these biistles are not prominent, but sessile, and are thus scarcely visible, except under a magnifying-glass; the ribs which divide the shining pentagonal plates or bosses are also studded with, for the most part a single row of, very minute, brown, shining, bristle-bearing tubercles.

This remarkable spider, which in its general appearance bears some resemblance to a small butterfly, shows a strong affinity both to the Gasteracanthides and to Arcys, and is evidently a transitional form ; but as it appears to me to be more nearly allied to the latter than to any of the groups of Gasteracanthides, not only by its general form, but by the peculiar structure of the cephalothorax, I have placed it along with Arcys in the family Arcydes; it differs, however, remarkably from Arcys in the general character and lengths of the legs, as also in the details of the abdominal scutum; for which and other reasons it has been necessary to constitute a new genus for its reception.

A single example was contained in a small collection of spiders from Madagascar, purchased of a London dealer in 1876. 


\section{List of Species.}

\section{Fam. Theraphosides.}

Atrax robustus , New Holland, p. 27, Pl. VI. fig. 1.

Idiophthalma suspecta $q$, Granada, South America, p. 27, Pl. VI. fig. 2.

Aganippe subtristis $ᄋ$, Adelaide, Australia, p. 28, Pl. VI. fig. 3.

latior $\$$, West Australia, p. 29, Pl. VI. fig. 4.

Eriodon insignis c, Swan River, Australia, p. 29, Pl. VI. fig. 5.

incertus of, Swan River, p. 30.

Fam. Phoroncidides.

Phoroncidia aurata , Madagascar, p. 31, Pl. VII. fig. 9.

Fam. Gasteracanthides.

Paraplectana maritata ${ }^{\star}$ and 9 , Ceylon, p. 32, Pl. VII. fig. 7.

decora 9 , Rio Grande, South America, p. 34, Pl. VII. fig. 8.

Kochii ơ, Cape York, Australia, p. 35, Pl. VII. fig. 10.

Fam. Arcydes.

Augusta papilionacea 옹, Madagascar, p. 37, Pl. VII. fig. 6 .

\section{EXPLANATION OF THE PLATES.}

\section{Plate VI.}

Fig. 1. Atrax robustus ㅇ: $a$, spider of natural size; $b$, cephalothorax and falces, in profile; $c$, eyes, from above and behind ; $d$, maxillæ, labium, and sternum.

Fig. 2. Idiophthalma suspecta ㅇ : $a$, spider, enlarged; $b$, cephalothorax and falces, in profile; $c$, eyes, from above and behind ; $d$, maxillæ and labium ; $e$, natural length to the extremity of the falces.

Fig. 3. Aganippe subtristis $q$ : $a$, spider, enlarged; $b$, cephalothorax and falces, in profile ; $c$, eyes, from above and behind ; $d$, maxillæ, labium, and sternum ; $e$, natural length to the extremity of the falces.

Fig. 4. Aganippe latior $q$ : $a$, spider, slightly enlarged ; $b$, cephalothorax and falces, in profile; $c$, eyes, from above and behind ; $d$, natural length to the extremity of the falces.

Fig. 5. Eriodon insignis $\delta^{*}: a$, spider, slightly enlarged; $b$, cephalothorax and falces, in profile ; $c$, eyes, from above and behind ; $d$, maxillæ, labium, and sternum; $e$, right palpus, from outer side ; $f$, extremity of tarsus of leg of first pair ; $g$, natural length to the extremity of the falces.

\section{Plate VII.}

Fig. 6. Augusta papilionacea ㅇ: $a$, spider, enlarged; $b$, caput and eyes, from in front; $c$, maxillæ, labium, and sternum; $d$, spider, of natural size.

Fig. 7. Paraplectana maritata $\delta^{*}$ and $q: a$, spider ( $q$ ), enlarged; $b$, ditto, in profile; $d$, ditto, natural size; $c$, spider ( $\left.\delta^{\circ}\right)$, enlarged; $e$, natural length of ditto.

Fig. 8. Paraplectana decora : $a$, spider, enlarged; $b$, ditto, natural size; $c$, ditto, in profile.

Fig. 9. Phoroncidia aurata ㅇ $: a$, spider, enlarged; $b$, ditto, in profile; $c$, view of abdomen, from behind; $d$, profile of caput; $e$, spider, of natural size.

Fig. 10. Paraplectana Kochii $q$ : $a$, spider, enlarged; $b$, ditto, in profile; $c$, ditto, natural size. 


\section{$2 \mathrm{BHL}$ Biodiversity Heritage Library}

Pickard-Cambridge, Octavius. 1877. "On some new genera and species of Araneidea." The Annals and magazine of natural history; zoology, botany, and geology 19, 26-39.

View This Item Online: https://www.biodiversitylibrary.org/item/85173

Permalink: https://www.biodiversitylibrary.org/partpdf/64185

\section{Holding Institution}

Smithsonian Libraries

\section{Sponsored by}

Smithsonian

\section{Copyright \& Reuse}

Copyright Status: Public domain. The BHL considers that this work is no longer under copyright protection.

This document was created from content at the Biodiversity Heritage Library, the world's largest open access digital library for biodiversity literature and archives. Visit BHL at https://www.biodiversitylibrary.org. 